\title{
Analisis Penyeimbangan Beban Pada Transformator Distribusi Menggunakan Metode Fuzzy
}

\author{
I Putu Weda Suryawan ${ }^{1}$, Anak Agung Ngurah Amrita ${ }^{2}$, Widyadi Setiawan ${ }^{3}$
}

\begin{abstract}
Load Balancing is basically provide the load on the transformer is in accordance with its capacity. Load Balancing is done on a transformer KA 0223 which supported by Bunisari Feeder and powered by the GI Pesanggaran. A transformer is located on Kubu Anyar Street Legian Kuta with the installed capacity of $200 \mathrm{kVA}$. The Transformer brand used is Starlite. The number of customers in a transformer KA 0223 as much as 173 customers. Measurement of load current is done at peak load that is at night. The data of measurement result then processed using Fuzzy method to get balanced result, the percentage of unbalance of load according to ANSI / IEEE Std 446-1987 is 5\% and to know the point of customer that must be added or subtracted. The data used in 2015 are in January and June, 2016 in January and June, in 2017 in January. Measurement results in the year 2017 January 1st semester percentage of load unbalance before using the Fuzzy method of $13.5 \%$. After using the Fuzzy method, the percentage of load unbalance is much better than before at $2.5 \%$. The measurement result of 2015 in 2sd semester is said to be balanced, because the percentage of load unbalance is equal to $5 \%$. After using Fuzzy method, the percentage of load unbalance is much better than before that is equal to $2.2 \%$. This proves that the program can work when the system is either balanced or not.
\end{abstract}

Intisari- Penyeimbangan beban pada dasarnya adalah memberikan beban pada transformator tersebut yang sesuai dengan kapasitasnya. Penyeimbangan beban ini dilakukan pada Trafo KA 0223 yang ditopang oleh Penyulang Bunisari dan dialiri daya oleh GI Pesanggaran. Trafo ini terletak di Jalan Kubu Anyar Legian Kuta dengan daya terpasang sebesar 200 kVA. Merk trafo yang digunakan adalah Starlite. Jumlah pelanggan pada trafo KA 0223 sebanyak 173 pelanggan. Pengukuran arus bebannya dilakukan pada saat beban puncak yaitu pada malam hari. Data - data hasil pengukuran selanjutnya diolah menggunakan metode Fuzzy untuk mendapatkan hasil yang seimbang. Persentase ketidakseimbang beban menurut ANSI/IEEE Std 446-1987 adalah 5\% dan mengetahui titik pelanggan yang harus ditambahkan atau dikurangkan. Data yang digunakan hasil pengukuran pada tahun 2015 yaitu pada bulan Januari dan Juni, tahun 2016 pada bulan Januari dan Juni, tahun 2017 pada bulan Januari. Hasil pengukuran pada tahun 2017 bulan Januari semester 1 persentase ketidakseimbangan beban sebelum menggunakan metode Fuzzy sebesar $13.5 \%$. Setelah menggunakan metode Fuzzy, persentase ketidakseimbangan beban jauh lebih baik dari sebelumnya yaitu sebesar $2.5 \%$. Hasil pengukuran tahun 2015 semester 2 dikatakan seimbang, karena persentase ketidakseimbangan bebannya sama dengan $5 \%$. Setelah

${ }^{1}$ Mahasiswa, Program Studi Teknik Elektro Fakultas Teknik Universitas Udayana, Jln. Kampus Bukit Jimbaran 80361 INDONESIA (telp: 0361-703315; fax: 0361-4321; e-mail: wedasurya2002@gmail.com

${ }^{2,3}$ Dosen, Program Studi Teknik Elektro Fakultas Teknik Universitas Udayana, Jln. Kampus Bukit Jimbaran 80361 INDONESIA (telp: 0361-703315; fax: 0361-4321; e-mail: 1ngr_amrita@ee.unud.ac.id, ${ }^{2}$ widyadi@unud.ac.id.

I Putu Weda Suryawan : Analisis Penyeimbangan Beban .... menggunakan metode Fuzzy, persentase ketidakseimbangan beban jauh lebih baik dari sebelumnya yaitu sebesar $2.2 \%$. Hal ini membuktikan bahwa program dapat bekerja pada saat sistem seimbang dan pada saat sistem tidak seimbang.

Kata Kunci — Fuzzy, Ketidakseimbangan Beban, Penyeimbangan Beban, Transformator.

\section{PENDAHULUAN}

Sistem distribusi merupakan salah satu sistem dalam tenaga listrik yang mempunyai peran penting karena berhubungan langsung dengan pemakai energi listrik, terutama pemakai energi listrik tegangan menengah dan tegangan rendah. Sering terjadi ketidakseimbangan beban pada sistem distribusi karena pemakaian alat-alat listrik dari konsumen. Ketidakseimbangan beban akan menyebabkan losses yang cukup besar pada arus netral antara tiap - tiap fasa pada trafo [1].

Kegiatan penyeimbangan beban transformator (trafo) distribusi merupakan kegiatan rutin yang dilakukan PLN setiap 6 bulan sekali. Hal ini dikarenakan selalu terjadi ketidakseimbangan beban antar fasa seiring dengan peningkatan jumlah pelanggan. Keadaan beban yang terus berubah, menimbulkan ketidakseimbangan beban pada fasa R, $\mathrm{S}$ dan $\mathrm{T}$ dan maka perlu dilakukan penyeimbangan beban secara berkala. Berikut data persentase ketidakseimbangan beban pada Trafo KA 0223 di penyulang Bunisari Legian Kuta pada bulan Januari 2017 semester 1 yang mencapai 13.5 $\%$. Persentase ketidakseimbangan menurut ANSI/IEEE Std 446-1987 adalah $5 \%$, oleh karena itu trafo tersebut harus dilakukan penyeimbangan beban [2].

Penelitian-penelitian terdahulu yang terkait dengan penyeimbangan trafo sudah banyak dilakukan, antara lain dengan metode seimbang beban seharian dan dengan aplikasi feeder sikakap. Pada penelitian ini penulis akan melakukan penyeimbangan beban dengan metode fuzzy. Pengaplikasian metode fuzzy pada penelitian ini karena memiliki banyak kelebihan dari metode terdahulu, salah satunya dalam hal proses pengolahan data lebih cepat dibandingkan metode seimbang beban seharian dan aplikasi feeder sikakap.

Teori fuzzy merupakan teori yang mudah untuk dipahami karena di dalam logika fuzzy terdapat konsep matematis sederhana yang mendasari penalaran fuzzy. Keunggulan logika fuzzy adalah dapat membangun dan mengaplikasikan pengalaman-pengalaman para pengunanya secara langsung tanpa harus melalui proses pelatihan, dapat memodelkan fungsi-fungsi nonlinier yang sangat kompleks dan dapat bekerjasama dengan teknik-teknik kendali secara konvensional [3]. 
Penelitian ini dapat membantu pihak PT.PLN untuk melakukan penyeimbangan beban, dikarenakan jika menggunakan logika fuzzy hasil output yang dihasilkan lebih akurat dan jika penyeimbangan beban tetap dilakukan dengan cara manual, maka akan memerlukan waktu lama.

\section{STUDI LITERATUR}

A. Keseimbangan Beban

Kebutuhan energi listrik menjadi kebutuhan utama bagi masyarakat. Dengan itu dibutuhkan cara penyaluran energi listrik yang sangat baik. Namun memang tidak akan ada hal yang ideal saat ini. Begitu pula dengan penyaluran energi listrik. Sistem penyaluran energi listrik yang dilakukan di Indonesia adalah sistem penyaluran dengan 3 fasa (fasa $R$, fasa S, dan fasa T) [9]. Selain itu Indonesia memakai sistem transmisi dan distribusi dimana sistem transmisi adalah sistem penyaluran daya dengan menaikkan tegangan yang selanjutnya diturunkan lagi pada sistem distribusi. Penggunaan energi listrik pelanggan sering kali memiliki jam operasi yang berbeda, akibatnya arus beban yang mengalir di setiap fasa tidak akan sama mengalir pada fasa netral [6]. Dalam proses menaikkan dan menurunkan tegangan digunakanlah transformator 3 fasa. Dalam keadaan ideal, transformator 3 fasa akan mempunyai nilai yang sama pada tiap fasanya, yang berbeda hanyalah sudut fasanya yaitu harus $120^{\circ}[4]$.

B. Syarat Keadaan Seimbang

1. Ketiga vektor arus/tegangan harus sama besar.

2. Ketiga vektor saling membentuk sudut $120^{\circ}$ satu dengan lain.

Penjelasan diatas merupakan syarat keadaan seimbang [8]. Untuk lebih jelas dapat dilihat pada gambar 1 .

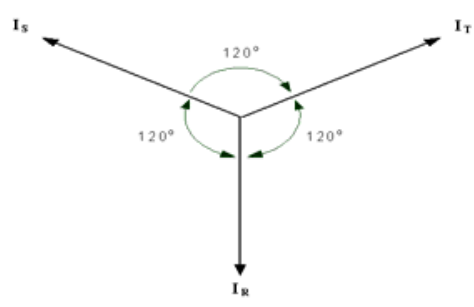

Gambar 1. Keadaan Seimbang [5]

Gambar 1 menunjukkan vektor arus dalam keadaan seimbang. Dapat dihat bahwa penjumlahan ketiga vektor arusnya $\left(\mathrm{I}_{\mathrm{R}}, \mathrm{I}_{\mathrm{S}}, \mathrm{I}_{\mathrm{T}}\right)$ adalah sama dengan nol sehingga tidak muncul arus netral $\left(\mathrm{I}_{\mathrm{N}}\right)$ [5].

\section{Fuzzy Logic}

Fuzzy logic atau sistem fuzzy merupakan suatu cara yang tepat untuk memetakan suatu ruang input ke dalam suatu

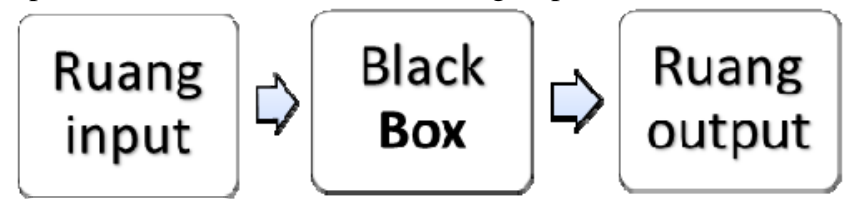

ruang output. untuk lebih jelasnya dapat dilihat pada gambar 2.

Gambar 2. Contoh Pemetaan input-output pada fuzzy logic [3]

D. Cara Kerja Logika Fuzzy

1. Fuzzyfikasi

Fuzzyfikasi merupakan proses yang berfungsi untuk mengubah untuk merubah suatu besaran analog menjadi fuzzy input.

2. Basis pengetahuan fuzzy

Pada pembentukan basis pengetahuan fuzzy berisi kumpulan aturan-aturan fuzzy dalam bentuk pernyataan IF...THEN.

3. Mesin Inferensi

Proses ini berfungsi untuk mencari suatu nilai fuzzy output dari fuzzy input. Proses dari mesin inferensi adalah suatu nilai fuzzy input yang berasal dari proses fuzzyfikasi kemudian dimasukkan kedalam sebuah rule yang telah dibuat untuk dijadikan sebuah fuzzy output.

4. Defuzzyfikasi

Merupakan proses terakhir dari serangkaian proses fuzzy. Proses defuzzyfikasi ialah mengubah output fuzzy yang diperoleh dari mesin infrensi menjadi nilai tegas menggunakan fungsi keanggotaan yang sesuai dengan saat dilakukan fuzzyfikasi [10].

\section{E. Fungsi Keanggotaan}

Fungsi keanggotaan adalah suatu kurva yang menunjukan pemetaan titik-titik input data ke dalam nilai keanggotaanya yang memiliki interval antara 0 sampai 1 [3]. Salah satu cara yang dapat digunakan untuk mendapatkan nilai keanggotaan adalah dengan melalui pendekatan fungsi [5]. Permukaan himpunan fuzzy yang merupakan bagian yang mendefinisikan fungsi kenaggotaan. biasanya permukaan tersebut berupa garis kontinyu yang bergerak dari kiri ke kanan [7]. Pada penelitian ini digunakan kurva segitiga, untuk ebih jelasnya dapat dilihat pada gambar 3 .

1. Representasi Kurva Segitiga

Kurva segitiga pada dasarnya merupakan gabungan antara 2 garis (linier) seperti terlihat pada gambar 3.

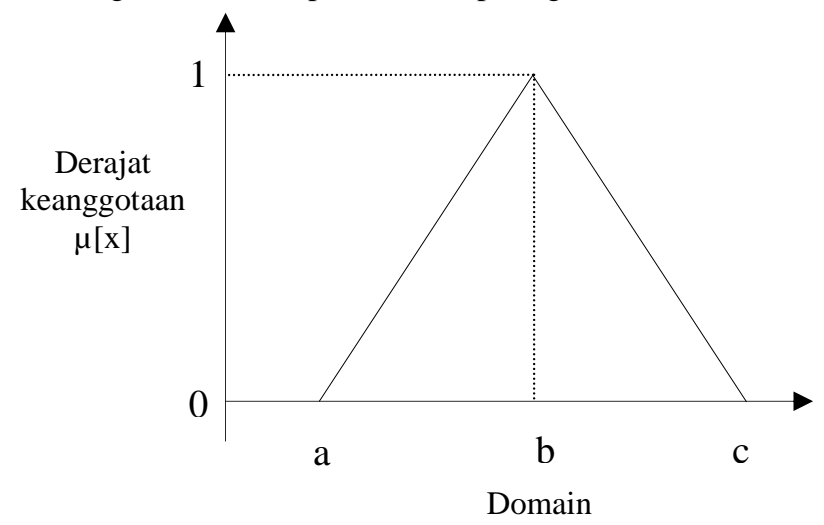




\section{METODE PENELITIAN}

Penelitian dilakukan di PT. PLN (Persero) Rayon Kuta Bali, dengan waktu pelaksanaan penelitian selama 4 bulan, dimulai dari bulan Oktober sampai bulan Januari tahun 2017. Alur analisis pada penelitian ini dapat dilihat pada gambar 4.

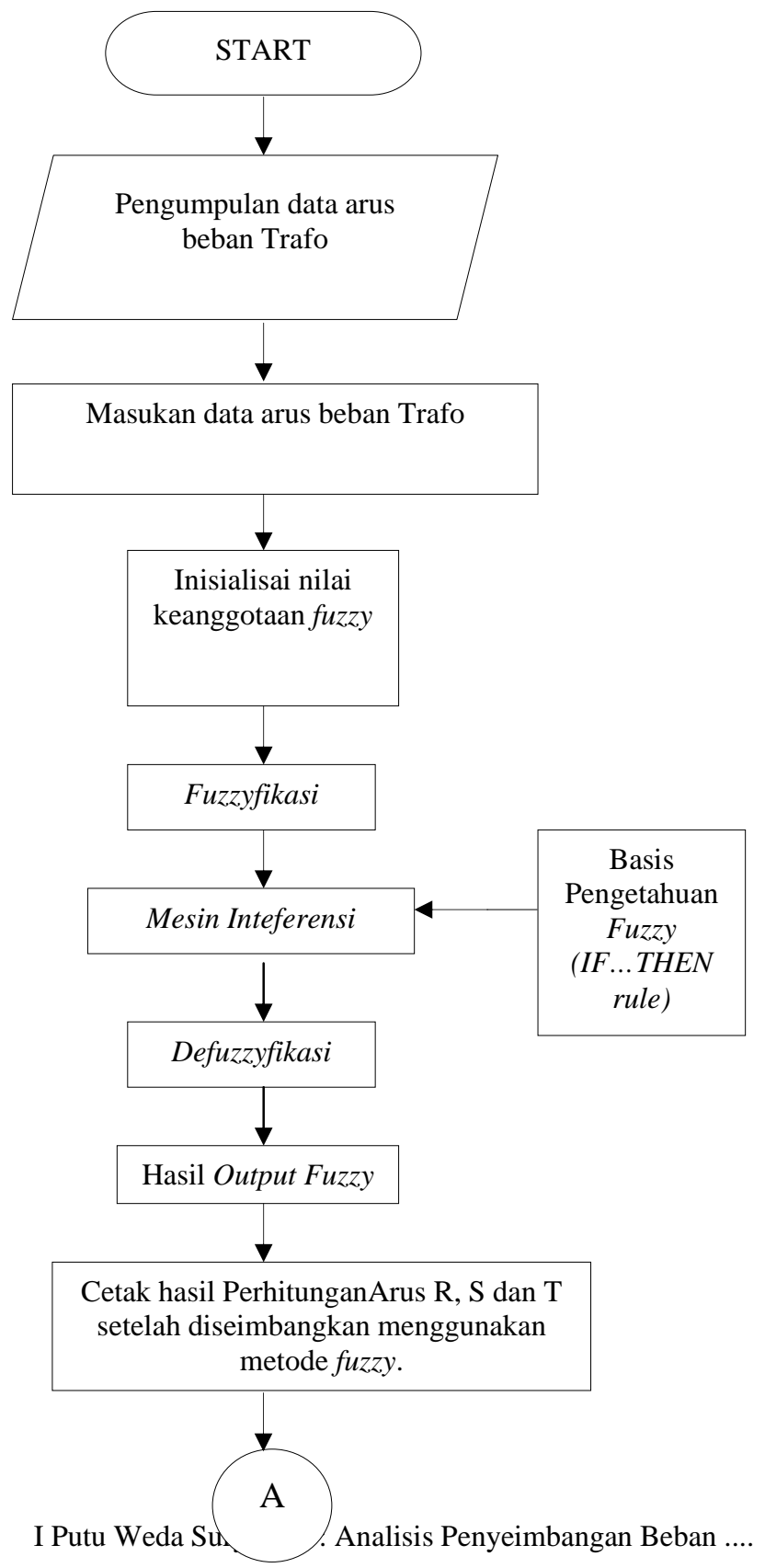

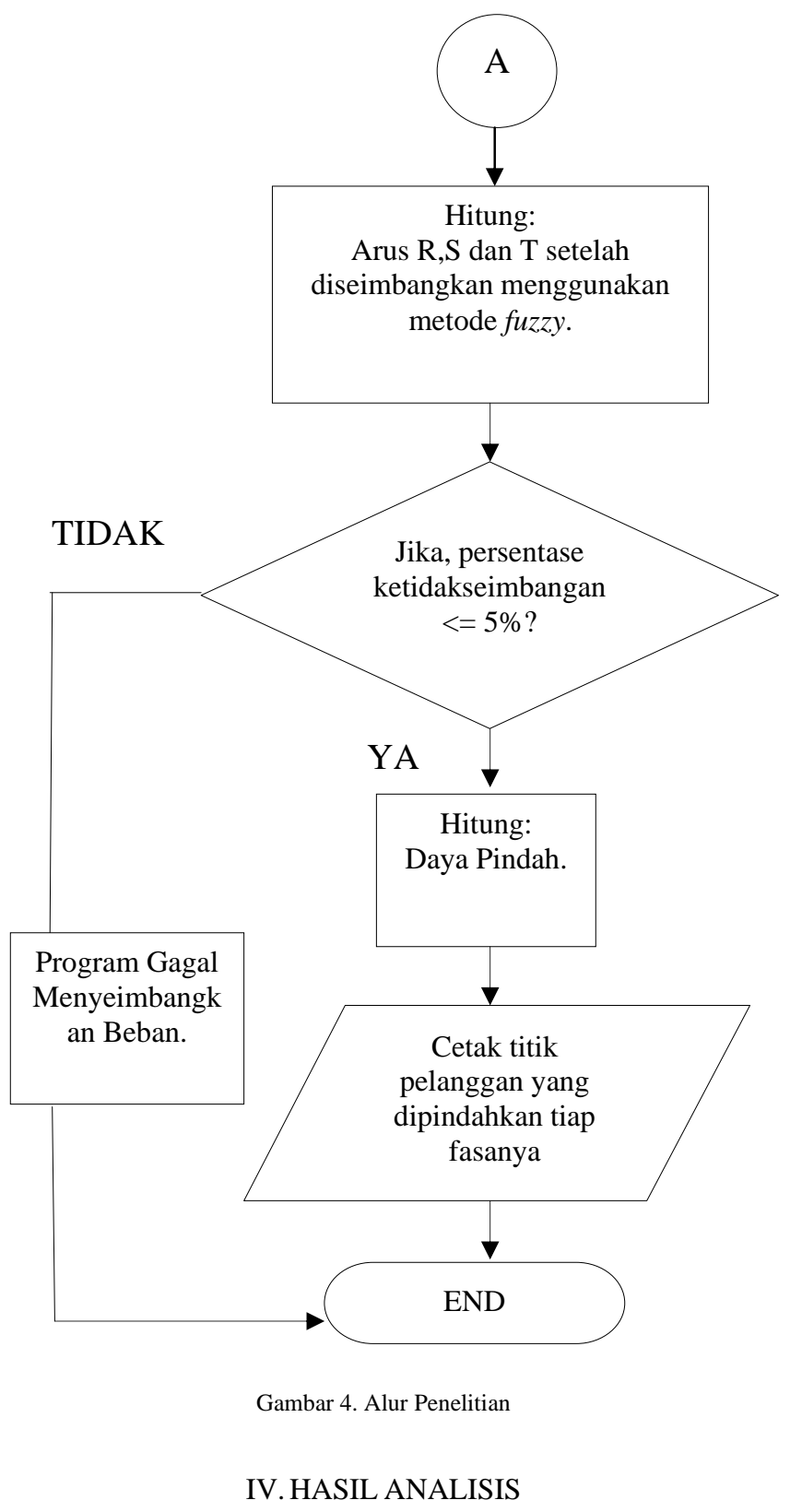

A. Hasil Pengukuran

Penyeimbangan beban pada dasarnya adalah memberikan beban pada transformator tersebut yang sesuai dengan kapasitasnya, sehingga yang dialiri beban dapat seimbang. Penyeimbangan beban ini dilakukan pada Trafo KA 0223 yang di topang oleh Penyulang Bunisari dan dialiri daya oleh GI Pesanggaran. Trafo ini terletak di Jalan Kubu

p-ISSN:1693 - 2951; e-ISSN: 2503-2372 
Anyar Legian Kuta dengan daya terpasang sebesar 200 kVA. Merk trafo yang digunakan adalah Starlite. Jumlah pelanggan pada trafo KA 0223 sebanyak 173 pelanggan. Untuk lebih jelas mengenai wujud real dari trafo yang dimaksud, dapat ditunjukan pada gambar 5 .

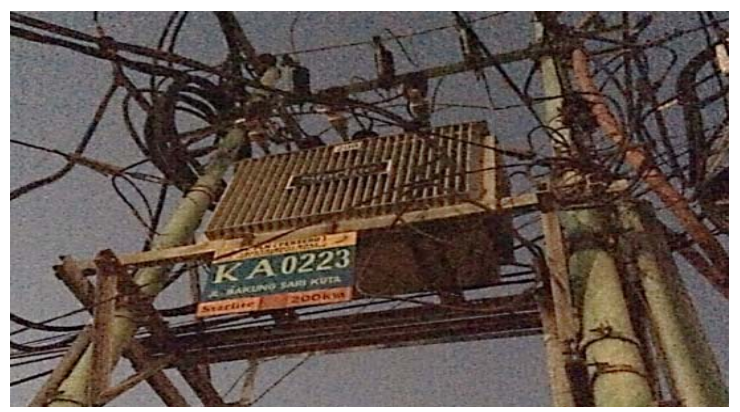

Gambar 5. Kondisi Trafo KA 0223 di jalan Kubu Anyar Legian Kuta

A. Data Beban Trafo KA 0223

Adapun data-data arus beban trafo yang digunakan sebagai input, antara lain:

TABEL I

DATA BEBAN TRAFO KA 0223

\begin{tabular}{cccccc}
\hline NO & Tahun & R (A) & S (A) & T (A) & \% Ketidakseimbangan Beban \\
\hline 1 & $2017(1)$ & 204 & 177 & 255 & 13.5 \\
2 & $2016(2)$ & 254 & 217 & 295 & 10.3 \\
3 & $2016(1)$ & 225 & 190 & 240 & 8.6 \\
4 & $2015(2)$ & 234 & 222 & 255 & 5 \\
5 & $2015(1)$ & 324 & 177 & 222 & 22.9 \\
\hline
\end{tabular}

Data Beban pada tabel I digunakan sebagai input fuzzy, agar mengetahui berapa beban yang harus ditambah atau dikurangkan untuk mendapatkan hasil beban yang seimbang.

B. Data Pelanggan Trafo KA 0223 Tahun 2016

\begin{tabular}{lllccc}
\hline $\mathbf{N}$ & NAMA & & & FASA & \\
$\mathbf{O}$ & PELANGGA & ALAMAT & R & S & T \\
& N & & (VA) & (VA) & (VA) \\
\hline 1 & $\begin{array}{l}\text { DARNATA I } \\
\text { MADE }\end{array}$ & GG. BEDURI JL SINGOSARI 9 & 900 & & \\
2 & I MADE JANI & GG PAHALA JL KUBU ANYAR & 900 & \\
3 & SUNI MADE & KRESEK JL KUBU ANYAR 12 & 4400 & \\
4 & $\begin{array}{l}\text { MINDRA I } \\
\text { NYOMAN }\end{array}$ & GG BEDURI JL SINGOSARI No.5 & 3500 & \\
5 & I MD MERTA & KUBU ANYAR 23 & 1300 & \\
& KASIR I & SINGOSARI 49 & & \\
6 & WAYAN & & &
\end{tabular}

Tabel II merupakan data pelanggan trafo KA 0223 Kuta Bali, antara lain:

TABEL II

\section{DATA PELANGGAN TRAFO KA 0223 TAHUN 2016}

Berdasarkan tabel II data pelanggan digunakan untuk mengetahui berapa jumlah pelanggan di masing - masing daya terpasang yang akan dipindahkan dari fasa semula ke fasa yang baru, agar mendapatkan hasil beban seimbang. Trafo tersebut lebih banyak menyuplai daya kepada konsumen rumah tangga, berdasarkan banyaknya pengguna daya antara lain daya 900 VA ada 23 pelanggan, daya 1300 VA ada 49 pelanggan, daya $2200 \mathrm{VA}$ ada 43 pelanggan dan daya 3500 VA ada 32 pelanggan. Proses penyeimbangan ini menggunakan 27 rule, dapat dilihat pada tabel III :

TABEL III

RULE FUZZY

\begin{tabular}{|c|c|}
\hline $\begin{array}{l}\text { Rule } \\
\text { No. }\end{array}$ & Rule Description \\
\hline 1 & $\begin{array}{l}\text { If (input-R is KurangBeban_R) or (input-S is } \\
\text { KurangBeban_S) or (input-T is KurangBeban_T) } \\
\text { then (output-R is } \\
\text { BanyakPenambahanBeban_R)(output-S is } \\
\text { BanyakPenambahanBeban_S)(output-T is } \\
\text { BanyakPenambahanBeban_T) (1) }\end{array}$ \\
\hline 2 & $\begin{array}{l}\text { If (input-R is KurangBeban_R) or (input-S is } \\
\text { KurangBeban_S) or (input-T is NormalBeban_T) } \\
\text { then (output-R is } \\
\text { BanyakPenambahanBeban_R)(output-S is } \\
\text { BanyakPenambahanBeban_S)(output-T is } \\
\text { PenambahanBeban_T) (1) }\end{array}$ \\
\hline 3 & $\begin{array}{l}\text { If (input-R is KurangBeban_R) or (input-S is } \\
\text { KurangBeban_S) or (input-T is LebihBeban_T) } \\
\text { then (output-R is } \\
\text { BanyakPenambahanBeban_R)(output-S is } \\
\text { BanyakPenambahanBeban_S)(output-T is } \\
\text { PenguranganBeban_T) (1) }\end{array}$ \\
\hline 4 & $\begin{array}{l}\text { If (input-R is KurangBeban_R) or (input-S is } \\
\text { NormalBeban_S) or (input-T is KurangBeban_T) } \\
\text { then (output-R is } \\
\text { BanyakPenambahanBeban_R)(output-S is } \\
\text { PenambahanBeban_S)(output-T is } \\
\text { BanyakPenambahanBeban_T) (1) }\end{array}$ \\
\hline 5 & $\begin{array}{l}\text { If (input-R is KurangBeban_R) or (input-S is } \\
\text { NormalBeban_S) or (input-T is NormalBeban_T) } \\
\text { then (output-R is } \\
\text { BanyakPenambahanBeban_R)(output-S is } \\
\text { PenambahanBeban_S)(output-T is } \\
\text { PenambahanBeban_T) (1) }\end{array}$ \\
\hline 6 & $\begin{array}{l}\text { If (input-R is KurangBeban_R) or (input-S is } \\
\text { NormalBeban_S) or (input-T is LebihBeban_T) } \\
\text { then (output-R is } \\
\text { BanyakPenambahanBeban_R)(output-S is } \\
\text { PenambahanBeban_S)(output-T is } \\
\text { PenguranganBeban_T) (1) }\end{array}$ \\
\hline 7 & $\begin{array}{l}\text { If (input-R is KurangBeban_R) or (input-S is } \\
\text { LebihBeban_S) or (input-T is KurangBeban_T) } \\
\text { then (output-R is } \\
\text { BanyakPenambahanBeban_R)(output-S is } \\
\text { PenguranganBeban_S)(output-T is } \\
\text { BanyakPenambahanBeban_T) (1) }\end{array}$ \\
\hline
\end{tabular}




\begin{tabular}{|c|c|}
\hline 8 & $\begin{array}{l}\text { If (input-R is KurangBeban_R) or (input-S is } \\
\text { LebihBeban_S) or (input-T is NormalBeban_T) } \\
\text { then (output-R is } \\
\text { BanyakPenambahanBeban_R)(output-S is } \\
\text { PenguranganBeban_S)(output-T is } \\
\text { PenambahanBeban_T) (1) }\end{array}$ \\
\hline 9 & $\begin{array}{l}\text { If (input-R is KurangBeban_R) or (input-S is } \\
\text { LebihBeban_S) or (input-T is LebihBeban_T) } \\
\text { then (output-R is } \\
\text { BanyakPenambahanBeban_R)(output-S is } \\
\text { PenguranganBeban_S)(output-T is } \\
\text { PenguranganBeban_T) (1) }\end{array}$ \\
\hline 10 & $\begin{array}{l}\text { If (input-R is NormalBeban_R) or (input-S is } \\
\text { KurangBeban_S) or (input-T is KurangBeban_T) } \\
\text { then (output-R is PenambahanBeban_R)(output-S } \\
\text { is BanyakPenambahanBeban_S)(output-T is } \\
\text { BanyakPenambahanBeban_T) (1) }\end{array}$ \\
\hline 11 & $\begin{array}{l}\text { If (input-R is NormalBeban_R) or (input-S is } \\
\text { KurangBeban_S) or (input-T is NormalBeban_T) } \\
\text { then (output-R is PenambahanBeban_R)(output-S } \\
\text { is BanyakPenambahanBeban_S)(output-T is } \\
\text { PenambahanBeban_T) (1) }\end{array}$ \\
\hline 12 & $\begin{array}{l}\text { If (input-R is NormalBeban_R) or (input-S is } \\
\text { KurangBeban_S) or (input-T is LebihBeban_T) } \\
\text { then (output-R is PenambahanBeban_R)(output-S } \\
\text { is BanyakPenambahanBeban_S)(output-T is } \\
\text { PenguranganBeban_T) (1) }\end{array}$ \\
\hline 13 & $\begin{array}{l}\text { If (input-R is NormalBeban_R) or (input-S is } \\
\text { NormalBeban_S) or (input-T is KurangBeban_T) } \\
\text { then (output-R is PenambahanBeban_R)(output-S } \\
\text { is PenambahanBeban_S)(output-T is } \\
\text { BanyakPenambahanBeban_T) (1) }\end{array}$ \\
\hline 14 & $\begin{array}{l}\text { If (input-R is NormalBeban_R) or (input-S is } \\
\text { NormalBeban_S) or (input-T is NormalBeban_T) } \\
\text { then (output-R is PenambahanBeban_R)(output-S } \\
\text { is PenambahanBeban_S)(output-T is } \\
\text { PenambahanBeban_T) (1) }\end{array}$ \\
\hline 15 & $\begin{array}{l}\text { If (input-R is NormalBeban_R) or (input-S is } \\
\text { NormalBeban_S) or (input-T is LebihBeban_T) } \\
\text { then (output-R is PenambahanBeban_R)(output-S } \\
\text { is PenambahanBeban_S)(output-T is } \\
\text { PenguranganBeban_T) (1) }\end{array}$ \\
\hline 16 & $\begin{array}{l}\text { If (input-R is NormalBeban_R) or (input-S is } \\
\text { LebihBeban_S) or (input-T is KurangBeban_T) } \\
\text { then (output-R is PenambahanBeban_R)(output-S } \\
\text { is PenguranganBeban_S)(output-T is } \\
\text { BanyakPenambahanBeban_T) (1) }\end{array}$ \\
\hline 17 & $\begin{array}{l}\text { If (input-R is NormalBeban_R) or (input-S is } \\
\text { LebihBeban_S) or (input-T is NormalBeban_T) } \\
\text { then (output-R is PenambahanBeban_R)(output-S } \\
\text { is PenguranganBeban_S)(output-T is } \\
\text { PenambahanBeban_T) (1) }\end{array}$ \\
\hline
\end{tabular}

I Putu Weda Suryawan : Analisis Penyeimbangan Beban ....

\begin{tabular}{|c|c|}
\hline 18 & $\begin{array}{l}\text { If (input-R is NormalBeban_R) or (input-S is } \\
\text { LebihBeban_S) or (input-T is LebihBeban_T) } \\
\text { then (output-R is PenambahanBeban_R)(output-S } \\
\text { is PenguranganBeban_S)(output-T is } \\
\text { PenguranganBeban_T) (1) }\end{array}$ \\
\hline 19 & $\begin{array}{l}\text { If (input-R is LebihBeban_R) or (input-S is } \\
\text { KurangBeban_S) or (input-T is KurangBeban_T) } \\
\text { then (output-R is PenguranganBeban_R)(output-S } \\
\text { is BanyakPenambahanBeban_S)(output-T is } \\
\text { BanyakPenambahanBeban_T) (1) }\end{array}$ \\
\hline 20 & $\begin{array}{l}\text { If (input-R is LebihBeban_R) or (input-S is } \\
\text { KurangBeban_S) or (input-T is NormalBeban_T) } \\
\text { then (output-R is PenguranganBeban_R)(output-S } \\
\text { is BanyakPenambahanBeban_S)(output-T is } \\
\text { PenambahanBeban_T) (1) }\end{array}$ \\
\hline 21 & $\begin{array}{l}\text { If (input-R is LebihBeban_R) or (input-S is } \\
\text { KurangBeban_S) or (input-T is LebihBeban_T) } \\
\text { then (output-R is PenguranganBeban_R)(output-S } \\
\text { is BanyakPenambahanBeban_S)(output-T is } \\
\text { PenguranganBeban_T) (1) }\end{array}$ \\
\hline 22 & $\begin{array}{l}\text { If (input-R is LebihBeban_R) or (input-S is } \\
\text { NormalBeban_S) or (input-T is KurangBeban_T) } \\
\text { then (output-R is PenguranganBeban_R)(output-S } \\
\text { is PenambahanBeban_S)(output-T is } \\
\text { BanyakPenambahanBeban_T) (1) }\end{array}$ \\
\hline 23 & $\begin{array}{l}\text { If (input-R is LebihBeban_R) or (input-S is } \\
\text { NormalBeban_S) or (input-T is NormalBeban_T) } \\
\text { then (output-R is PenguranganBeban_R)(output-S } \\
\text { is PenambahanBeban_S)(output-T is } \\
\text { PenambahanBeban_T) (1) }\end{array}$ \\
\hline 24 & $\begin{array}{l}\text { If (input-R is LebihBeban_R) or (input-S is } \\
\text { NormalBeban_S) or (input-T is LebihBeban_T) } \\
\text { then (output-R is PenguranganBeban_R)(output-S } \\
\text { is PenambahanBeban_S)(output-T is } \\
\text { PenguranganBeban_T) (1) }\end{array}$ \\
\hline 25 & $\begin{array}{l}\text { If (input-R is LebihBeban_R) or (input-S is } \\
\text { LebihBeban_S) or (input-T is KurangBeban_T) } \\
\text { then (output-R is PenguranganBeban_R)(output-S } \\
\text { is PenguranganBeban_S)(output-T is } \\
\text { BanyakPenambahanBeban_T) (1) }\end{array}$ \\
\hline 26 & $\begin{array}{l}\text { If (input-R is LebihBeban_R) or (input-S is } \\
\text { LebihBeban_S) or (input-T is NormalBeban_T) } \\
\text { then (output-R is PenguranganBeban_R)(output-S } \\
\text { is PenguranganBeban_S)(output-T is } \\
\text { PenambahanBeban_T) (1) }\end{array}$ \\
\hline 27 & $\begin{array}{l}\text { If (input-R is LebihBeban_R) or (input-S is } \\
\text { LebihBeban_S) or (input-T is LebihBeban_T) } \\
\text { then (output-R is PenguranganBeban_R)(output-S } \\
\text { is PenguranganBeban_S)(output-T is } \\
\text { PenguranganBeban_T) (1) }\end{array}$ \\
\hline
\end{tabular}

Setelah di proses dengan 27 rule akan menghasilkan p-ISSN:1693 - 2951; e-ISSN: 2503-2372 
nilai output fuzzy. Berikut merupakan hasil output fuzzy pada software MATLAB pada tabel IV.

TABEL IV

HASIL PROSES FUZZY PADA MATLAB

\begin{tabular}{cccccccc}
\hline No & $\begin{array}{c}\text { Tahun } \\
\text { (semester) }\end{array}$ & $\begin{array}{c}\text { Input } \\
\text { R (A) }\end{array}$ & $\begin{array}{c}\text { Input } \\
\text { S (A) }\end{array}$ & $\begin{array}{c}\text { Input } \\
\text { T (A) }\end{array}$ & $\begin{array}{c}\text { Output } \\
\text { R (A) }\end{array}$ & $\begin{array}{c}\text { Output } \\
\text { S (A) }\end{array}$ & $\begin{array}{c}\text { Output } \\
\text { T (A) }\end{array}$ \\
\hline 1 & $2017(1)$ & 204 & 177 & 255 & 0.1 & 17.9 & -66.2 \\
2 & $2016(2)$ & 254 & 217 & 295 & -65.2 & -6 & -109.1 \\
3 & $2016(1)$ & 225 & 190 & 240 & -25.6 & 0.4 & -49.8 \\
4 & $2015(2)$ & 234 & 222 & 255 & -41.5 & -19 & -66.2 \\
5 & $2015(1)$ & 324 & 177 & 222 & -116.6 & 17.9 & -19 \\
\hline
\end{tabular}

Berdasarkan tabel IV, dapat dilihat hasil nilai output dari proses fuzzy.

C. Mencari Besar Arus R, S dan T Setelah Diseimbangkan Menggunakan Metode Fuzzy

Setelah mendapatkan hasil output fuzzy, maka didapat hasil perhitungan dari besar arus $\mathrm{R}, \mathrm{S}$ dan $\mathrm{T}$ setelah diseimbangkan menggunakan metode fuzzy. Untuk hasil lebih jelasnya dapat dilihat pada tabel V.

TABEL V

BESAR ARUS R, S DAN T SETELAH DISEIMBANGKAN MENGGUNAKAN METODE FUZZY

\begin{tabular}{cccccccc}
\hline \multirow{2}{*}{ No } & $\begin{array}{c}\text { Tahun } \\
\text { (semester) }\end{array}$ & $\begin{array}{c}\text { R } \\
\text { (A) }\end{array}$ & $\begin{array}{c}\text { S } \\
\text { (A) }\end{array}$ & $\begin{array}{c}\text { T } \\
\text { (A) }\end{array}$ & $\begin{array}{c}\text { R } \\
\text { (A) }\end{array}$ & $\begin{array}{c}\text { S } \\
\text { (A) }\end{array}$ & $\begin{array}{c}\text { T } \\
\text { (A) }\end{array}$ \\
\hline 1 & $2017(1)$ & 204 & 177 & 255 & 220 & 211 & 205 \\
2 & $2016(2)$ & 254 & 217 & 295 & 249 & 271 & 246 \\
3 & $2016(1)$ & 225 & 190 & 240 & 224 & 215 & 216 \\
4 & $2015(2)$ & 234 & 222 & 255 & 234 & 245 & 232 \\
5 & $2015(1)$ & 324 & 177 & 222 & 246 & 234 & 243
\end{tabular}

Berdasarkan tabel V, dapat dilihat besar arus phasa R, S dan T setelah diseimbangkan.

D. Mencari Persentase Ketidakseimbangan Beban

Setelah mendapatkan hasil yang seimbang, maka didapat hasil perhitungan dari persentase ketidakseimbangan beban, dapat dilihat pada tabel VI.

TABEL VI

HASIL PERHITUNGAN PERSENTASE KETIDAKSEIMBANGAN BEBAN

\begin{tabular}{cccc}
\hline No & Tahun (semester) & $\begin{array}{c}\text { Persentase Sebelum } \\
\text { (\%) }\end{array}$ & $\begin{array}{c}\text { Persentase Sesudah } \\
\text { (\%) }\end{array}$ \\
\hline 1 & $2017(1)$ & 13.5 & 2.5 \\
2 & $2016(2)$ & 10.3 & 4 \\
3 & $2016(1)$ & 8.6 & 1.7 \\
4 & $2015(2)$ & 5 & 2.2 \\
5 & $2015(1)$ & 22.9 & 1.9 \\
\hline
\end{tabular}

Berdasarkan tabel VI, dapat dilihat hasil persentase ketidakseimbangan bebannya.
E. Mencari Jumlah Pelanggan Yang Harus Dipindahkan Berdasarkan Daya

Setelah mendapatkan hasil daya pindah, maka didapat hasil jumlah titik sambung yang harus dipindahkan dari masing-masing fasa yang dimulai dari fasa $\mathrm{R}, \mathrm{S}, \mathrm{T}$ dan dimulai dari daya 900 VA, 1300 VA, 2200 VA. Untuk hasil lebih jelas dapat dilihat pada tabel VII.

TABEL VII

HASIL PERHITUNGAN JUMLAH PELANGGAN YANG HARUS DIPINDAHKAN BERDASARKAN DAYA

\begin{tabular}{|c|c|c|c|c|c|c|c|c|c|c|}
\hline \multirow{3}{*}{ No } & \multirow{3}{*}{$\begin{array}{c}\text { Tahun } \\
\text { (semes } \\
\text { ter) }\end{array}$} & \multicolumn{9}{|c|}{ Daya } \\
\hline & & \multicolumn{3}{|c|}{900 (VA) } & \multicolumn{3}{|c|}{1300 (VA) } & \multicolumn{3}{|c|}{2200 (VA) } \\
\hline & & $\mathbf{R}$ & S & $\mathbf{T}$ & $\mathbf{R}$ & S & $\mathbf{T}$ & $\mathbf{R}$ & $\mathrm{s}$ & $\mathrm{T}$ \\
\hline 1 & $\begin{array}{c}2017 \\
\text { (1) }\end{array}$ & +5 & +12 & -17 & +4 & +8 & -12 & +2 & +5 & -7 \\
\hline 2 & $\begin{array}{c}2016 \\
(2)\end{array}$ & -1 & +15 & -14 & -1 & +11 & -10 & -1 & +6 & -5 \\
\hline 3 & $\begin{array}{c}2016 \\
(1)\end{array}$ & 0 & +8 & -8 & 0 & +6 & -6 & 0 & +3 & -3 \\
\hline 4 & $\begin{array}{c}2015 \\
\text { (2) }\end{array}$ & 0 & +7 & -7 & 0 & +5 & -5 & 0 & +3 & -3 \\
\hline 5 & $\begin{array}{c}2015 \\
(1)\end{array}$ & -24 & +18 & +6 & -17 & +12 & +4 & -10 & +7 & +3 \\
\hline
\end{tabular}

Ket:

+ Ditambahkan

- Dikurangkan

Berdasarkan tabel VII dimana jumlah pelanggan yang harus ditambah dan dikurangkan tiap fasanya pada tahun 2017 (1) untuk daya 900 VA pada fasa R ditambahkan sebanyak 5 pelanggan, fasa $\mathrm{S}$ ditambahkan sebanyak 12 pelanggan dan fasa T dikurangkan sebanyak 17 pelanggan. Untuk daya 1300 VA pada fasa R ditambahkan sebanyak 4 pelanggan, pada fasa $\mathrm{S}$ ditambahkan sebanyak 8 pelanggan dan fasa T dikurangkan sebanyak 12 pelanggan. Untuk daya 2200 VA pada fasa R ditambahkan sebanyak 2 pelanggan, pada fasa $S$ ditambahakan sebanyak 5 pelanggan dan fasa T dikurangkan sebanyak 7 pelanggan. Pada tahun 2015 (1) untuk daya 900 VA pada fasa R dikurangkan sebanyak 24 pelanggan, fasa S ditambahkan sebanyak 18 pelanggan dan fasa T ditambahkan sebanyak 6 pelanggan. Untuk daya 1300 VA pada fasa R dikurangkan sebanyak 17 pelanggan, pada fasa S ditambahkan sebanyak 12 pelanggan dan fasa T ditambahkan sebanyak 5 pelanggan. Untuk daya 2200 VA pada fasa R dikurangkan sebanyak 10 pelanggan, pada fasa $\mathrm{S}$ ditambahakan sebanyak 7 pelanggan dan fasa $\mathrm{T}$ ditambahkan sebanyak 3 pelanggan, begitu juga dengan tahun berikutnya.

\section{KESIMPULAN}

Berdasarkan hasil pembahasan diatas dapat ditarik 3 simpulan sebagai berikut; 
Majalah Ilmiah Teknologi Elektro, Vol. 17, No. 1,Januari -April 2018

DOI: https://doi.org/10.24843/MITE.2018.v17i01.P19

1. Hasil perhitungan penyeimbangan beban pada tiap fasanya berdasarkan tahunnya mendapatkan hasil yang lebih baik yaitu pada tahun 2017 (1) pada fasa R sebesar 220 A, fasa S sebesar 211 A dan fasa T sebesar 205 A. Pada tahun 2015 (1) pada fasa R sebesar 246 A, pada fasa S sebesar 234 A dan fasa T sebesar 243 A. Hasil tersebut menunjukkan bahwa logika fuzzy dapat bekerja dengan baik dalam mencari nilai keseimbangan beban.

2. Hasil perhitungan persentase ketidakseimbangan beban pada tahun 2017 (1) sebelum menggunakan logika fuzzy sebesar $13.5 \%$ dan sesudah menggunakan logika fuzzy sebesar 2.5\%. Pada tahun 2015 (1) sebelum menggunakan logika fuzzy sebesar $22.9 \%$ dan sesudah menggunakan logika fuzzy sebesar $1.9 \%$. Hasil tersebut menunjukan bahwa logika fuzzy dapat bekerja dengan baik dalam mencari nilai persentase ketidakseimbangan beban.

3. Hasil perhitungan jumlah pelanggan yang harus ditambah dan dikurangkan tiap fasanya pada tahun 2017 (1) untuk daya 900 VA pada fasa R ditambahkan sebanyak 5 pelanggan, fasa S ditambahkan sebanyak 12 pelanggan dan fasa $\mathrm{T}$ dikurangkan sebanyak 17 pelanggan. Untuk daya 1300 VA pada fasa R ditambahkan sebanyak 4 pelanggan, pada fasa $\mathrm{S}$ ditambahkan sebanyak 8 pelanggan dan fasa $\mathrm{T}$ dikurangkan sebanyak 12 pelanggan. Untuk daya 2200 VA pada fasa $\mathrm{R}$ ditambahkan sebanyak 2 pelanggan, pada fasa $\mathrm{S}$ ditambahakan sebanyak 5 pelanggan dan fasa $\mathrm{T}$ dikurangkan sebanyak 7 pelanggan. Pada tahun 2015 (1) untuk daya 900 VA pada fasa R dikurangkan sebanyak 24 pelanggan, fasa S ditambahkan sebanyak 18 pelanggan dan fasa $\mathrm{T}$ ditambahkan sebanyak 6 pelanggan. Untuk daya $1300 \mathrm{VA}$ pada fasa R dikurangkan sebanyak 17 pelanggan, pada fasa S ditambahkan sebanyak 12 pelanggan dan fasa $T$ ditambahkan sebanyak 5 pelanggan. Untuk daya 2200 VA pada fasa $\mathrm{R}$ dikurangkan sebanyak 10 pelanggan, pada fasa S ditambahakan sebanyak 7 pelanggan dan fasa $\mathrm{T}$ ditambahkan sebanyak 3 pelanggan, begitu juga dengan tahun berikutnya.

\section{REFERENSI}

[1] Antonov dkk, 2015, "Optimasi Penyeimbangan Beban Pada Trafo Distribusi Terhadap Susut Energi (Aplikasi Feeder Sikakap)”, Padang.

[2] John Wiley, 1987.IEEE Recommended Practice for Emergency and Standy Power Systems for Industrial and Commercial Application. New York.

[3] Kusumadewi, S. 2002. Analisa dan Desain Sistem Fuzzy Menggunakan Toolbox Matlab. Yogyakarta: Graha Ilmu.

[4] Sutojo, dkk. 2010. Kecerdasan Buatan. Semarang: Andi.

[5] Siswoyo.2008. Teknik Listrik Industri Jilid 3. Jakarta.

[6] A.M.Putra dkk, 2016, 'Rancang Bangun Penyeimbangan Arus Beban Pada Sistem 3 Fasa Menggunakan Mikrokontroller Atmega 2560", Jimbaran Bali.

I Putu Weda Suryawan : Analisis Penyeimbangan Beban ....
[7] Rukmi Sari Hartati dkk, 2007, '’Penerapan Theorema Fuzzy Untuk Menentukan Lokasi Pemasangan Dan Kapasitas Kapasitor Pada Saluran Distribusi Primer', Jimbaran Bali.

[8] Gassing \& Indra Jaya, 2013, '’oprimalisasi Pembebanan Transformator Distribusi Dengan Penyeimbangan Beban ', , Makassar.

[9] Prasetya Ulah Sakti, 2008, “' Evaluasi Pemerataan Beban Untuk Menekan Losses Jaringan Tegangan Rendah Di Gardu E311P Dan Gardu PM213”, , Jakarta.

[10] Fanoeel Thamrin, 2012 , 'Studi Inferensi Fuzzy Tsukamoto Untuk Penentuan Faktor Pembebanan Trafo PLN', Semarang. 